\title{
WAWASAN NUSANTARA : SEBAGAI SATU KESATUAN POLITIK, EKONOMI, SOSIAL BUDAYA DAN HANKAM
}

\author{
Ramadhan Yusuf Firdhaus \\ IIK STRADA INDONESIA
}

yframa@gmail.com

\begin{abstract}
Abstrak
Indonesia adalah negara yang memiliki berbagai keragaman di dalamnya. Misalnya dlihat dari suku bangsanya, negara ini terdiri dari berbagai suku seperti Jawa Sunda, Dayak, Bugis, dan sebagainya. Dari setiap suku bangsa memiliki beraneka budaya yang memperkaya corak budaya asli Indonesia. Semua keanekaragaman tersebut memerlukan persatuan. Bagaimana cara perwujudan wawasan nusantara sebagai satu kesatuan politik, kesatuan sosial dan budaya, kesatuan ekonomi, serta kesatuan hankam. Penerapan nyata wawasan nusantara dapat dilakukan melalui cara berpikir, bersikap, bahkan berucap. Dengan demikian, wawasan Nusantara juga dapat diartikan sebagai cara pandang bangsa Indonesia tentang diri dan lingkungannya berdasarkan ide nasionalnya yang dilandasi oleh Pancasila dan UUD 1945, yang merupakan aspirasi bangsa yang merdeka, berdaulat, bermartabat, serta menjiwai tata hidup dan tindak kebijaksanaannya dalam mencapai tujuan nasional.
\end{abstract}

\section{Kata Kunci : Wawasan Nusantara, UUD 1945}

\begin{abstract}
Indonesia is a country that has a variety of diversity in it. For example, seen from the tribe, this country consists of various tribes such as SundaNese Java, Dayak, Bugis, and so on. From each tribe has a variety of cultures that enrich the original cultural patterns of Indonesia. All of this diversity requires unity. How to realize the insight of the archipelago as a political unity, social and cultural unity, economic unity, and hankam unity. The real application of nusantara insight can be done through thinking, behaving, even speaking. Thus, nusantara insight can also be interpreted as the Indonesian nation's view of themselves and their environment based on their national ideas based on Pancasila and the 1945 Constitution, which is the aspiration of an
\end{abstract}


independent, sovereign, dignified nation and animates its lifestyle and wisdom in achieving national goals.

\section{Keywords :Nusantara Insight, 1945 Constitution}

\section{A. Latar Belakang}

Indonesia adalah negara yang memiliki berbagai keragaman di dalamnya. Misalnya dlihat dari suku bangsanya, negara ini terdiri dari berbagai suku seperti Jawa Sunda, Dayak, Bugis, dan sebagainya. Dari setiap suku bangsa memiliki beraneka budaya yang memperkaya corak budaya asli Indonesia. Semua keanekaragaman tersebut memerlukan persatuan. Dengan persatuan, maka semua yang tampak berbeda itu dapat bersatu sebagai kebulatan yang utuh. Dan, bersatu bangsa didorong dari kemauan secara sadar dan penuh tanggung jawab dalam mencapai kehidupan bangsa yang bebas di suatu wadah negara merdeka, berdaulat, adil, dan makmur. Menurut buku PPKN Kelas XI (Kemdikbud 2017), kesatuan bangsa adalah kondisi yang utuh yang memperlihatkan keamanan, kesentosaan, dan kejayaan. Oleh sebab itu, unsur aman, sentosa, dan jaya bisa didapatkan ketika sudah tercipta kondisi kesatuan bangsa. Menurut laman Kementrian Keuangan, persatuan dan kesatuan adalah prasyarat utama jika ingin melakukan pembangunan di suatu negara. Dalam kemajemukan masyarakat diperlukan kemampuan menjaga, mengembangkan, dan mewujudkan persatuan dan kesatuan di dalam kehidupan masyarakat. Sementara itu, wujud kesatuan bangsa dapat ditinjau dari berbagai sisi seperti politik, ekonomi, sosial budaya, dan pertahanan keamanan . Perwujudan Wawasan Nusantara sebagai kesatuan dalam mencapai tujuan Pembangunan Nasional mencakup beberapa aspek kesatuan, seperti kesatuan politik, ekonomi, sosial budaya, dan pertahanan keamanan (hankam). Wawasan berarti pandangan, tinjauan, penglihatan, atau tanggap indrawi. Selain menunjukkan kegiatan untuk mengetahui arti pengaruh-pengaruhnya dalam kehidupan berbangsa dan bernegara, wawasan juga memiliki pengertian menggambarkan cara pandang, cara tinjau, cara melihat, atau cara tanggap indrawi. Kata "nasional" menunjukkan kata sifat atau ruang lingkup. Bentuk kata yang berasal dari istilah nation itu berarti bangsa yang telah mengidentifikasikan diri ke dalam kehidupan bernegara atau secara singkat dapat dikatakan sebagai bangsa yang telah menegara. Adapun "Nusantara" adalah istilah yang digunakan untuk menggambarkan suatu wilayah

perairan dan gugusan pulau-pulau yang terletak di antara Samudera Pasifik dan Samudera Indonesia, serta di antara benua Asia dan Australia. 


\section{B. Kasus / Masalah}

Bagaimana cara perwujudan wawasan nusantara sebagai satu kesatuan politik, kesatuan sosial dan budaya, kesatuan ekonomi, serta kesatuan hankam.

\section{Tinjauan Pustaka}

Pengertian wawasan nusantara secara etimologi berasal dari bahasa Jawa wawas yang berarti pandangan, nusa yang berarti kesatuan kepulauan dan antara yang bermakna dua samudera. Jadi pengertian secara umum dari Wawasan nusantara adalah cara pandang atau cara melihat kesatuan kepulauan yang terletak diantara (Asia dan Australia) juga dua samudera (Hindia dan Pasifik).

Berdasarkan TAP MPR tahun 1993 dan 1998 tentang GBHN, wawasan nusantara adalah cara pandang dan sikap bangsa Indonesia, tentang jati diri dan lingkungan yang mengutamakan persatuan dan kesatuan bangsa, serta kesatuan wilayah demi tercapainya tujuan nasional.

Sementara pengertian Wawasan Nusantara menurut dokumen ketetapan MPR tahun 1999 menyatakan: "Wawasan nusantara adalah cara pandang dan sikap bangsa mengenai diri dan lingkungan yang serba beragam dan bernilai strategis dengan mengutamakan persatuan dan kesatuan bangsa serta wilayah dalam menyelenggarakan kehidupan bermasyarakat, berbangsa, dan bernegara dengan tujuan mencapai tujuan nasional."

Wawasan nusantara memiliki dua tujuan yaitu :

1. Tujuan wawasan nusantara ke luar adalah menjamin kepentingan nasional dalam era globalisasi yang kian mendunia maupun kehidupan dalam negeri. Kemudian turut serta melaksanakan ketertiban dunia berdasarkan kemerdekaan, perdamaian abadi, keadilan sosial, dengan sikap saling menghormati. Bangsa Indonesia harus terus-menerus mengamankan dan menjaga kepentingan nasionalnya dalam kehidupan internasionalnya di semua aspek kehidupan, baik politik, ekonomi, sosial budaya maupun pertahanan dan keamanan demi tercapainya tujuan nasional yang tertera dalam UUD 1945.

2. Tujuan wawasan nusantara ke dalam adalah menjamin persatuan dan kesatuan di segenap aspek kehidupan nasional, baik aspek alamiah maupun aspek sosial. Bangsa Indonesia harus meningkatkan kepekaannya dan berupaya mencegah faktor-faktor penyebab timbulnya disintegrasi bangsa sedini mungkin, juga terus mengupayakan terjaganya persatuan dan kesatuan dalam kebhinekaan. 
Jika mengacu pada pengertian wawasan nusantara, sebenarnya fungsi utama dari wawasan nusantara adalah sebagai panduan, pedoman, acuan bagi bangsa Indonesia dalam bernegara. Fungsi wawasan nusantara sendiri terbagi lagi ke dalam 4 kategori, yaitu:

1. Wawasan pertahanan dan keamanan nasional : Mengarah pada pandangan geopolitik negara Indonesia. Pandangan tersebut mencakup tanah air serta segenap wilayah Kesatuan Negara Republik Indonesia .

2. Wawasan Kewilayahan Indonesia: Termasuk pemahaman mengenai batas wilayah Indonesia agar terhindar dari potensi sengketa dengan negara lain .

3. Wawasan Pembangunan: Dengan beberapa unsur di dalamnya, seperti sosial politik, kesatuan politik, pertahanan serta keamanan negara, ekonomi, dan sosial ekonomi.

4. Konsep Ketahanan Nasional: Konsep ketahanan sosial yang memegang peranan penting dalam perencanaan pembangunan, kewilayahan, serta pertahanan keamanan nasional.

\section{C.1 Asas Wawasan Nusantara}

Asas wawasan nusantara merupakan kaidah atau ketentuan dasar yang wajib dipatuhi, dilakukan, serta dijaga oleh seluruh elemen masyarakat agar tercipta perdamaian serta keseimbangan di Indonesia. Secara keseluruhan ada 6 asas wawasan nusantara yang wajib kamu pahami, diantaranya:

\section{Asas Solidaritas}

Solidaritas adalah perasaan emosional dan moral yang terbentuk pada hubungan antar individu atau kelompok berdasarkan rasa saling percaya, kesamaan tujuan dan cita-cita, adanya kesetiakawanan dan rasa sepenanggungan.

Sikap solidaritas sendiri merupakan bentuk kepedulian terhadap orang lain. Sikap solidaritas sudah selayaknya dijalankan oleh seluruh masyarakat Indonesia, tanpa membeda-bedakan dari dan kepada siapa.

Kesetiaan menjadi tonggak utama dalam menciptakan persatuan serta kesatuan suatu negara. Rasa setia kawan atau solidaritas dapat menjadi kekuatan tersendiri untuk mewujudkan tujuan dan cita-cita nasional.

2. Asas Kejujuran

Kejujuran dalam berpikir serta bertindak menjadi sebuah asas wawasan nusantara yang sangat penting. Berani berpikir dan bertindak hanya yang sesuai dengan fakta serta kenyataan, wajib 
dilakukan demi tercapainya kemajuan.

3. Asas Kesamaan Tujuan

Mempunyai tujuan serta kepentingan yang sama. Sebagai contoh, di masa kemerdekaan saat semua rakyat Indonesia melakukan berjuang bersama-sama mengusir para penjajah.

4. Asas Keadilan

Seluruh elemen masyarakat mempunyai hak yang sama dalam mendapatkan keadilan dan mewujudkan tujuan serta cita-cita nasional tidak boleh merugikan pihak tertentu maupun mengutamakan kepentingan kelompok atau golongan sendiri. Hal ini berlaku dalam segala aspek kehidupan bernegara, baik keadilan secara hukum, ekonomi, politik, serta sosial.

\section{Asas Kerja Sama}

Dengan adanya kesadaran pada tujuan serta kepentingan yang sama akan menciptakan kerjasama antar elemen masyarakat. Kerjasama serta koordinasi tersebut dapat dilaksanakan atas dasar kesetaraan agar terciptanya efektivitas dalam mencapai tujuan bersama. Sebab kebersamaan dan gotong royong ini akan memudahkan serta meringankan suatu pekerjaan termasuk dalam menghadapi tantangan terhadap implementasi wawasan nusantara.

\section{Pembahasan}

Penerapan nyata wawasan nusantara dapat dilakukan melalui cara berpikir, bersikap, bahkan berucap. Contoh penerapan wawasan nusantara sendiri dimulai dari menjadikan Pancasila sebagai falsafah dan pedoman hidup bernegara serta bermasyarakat. Hal ini bisa atau dapat dilakukan dengan tindakan nyata sehari-hari yang mencerminkan nilai-nilai religius, kekeluargaan, serta menjaga persatuan sesuai dengan Pancasila. Sikap cinta tanah air yang diwujudkan dengan adanya sikap yang lebih menitikberatkan pada kepentingan bangsa serta negara di atas kepentingan pribadi, golongan, serta agama. Mewujudkan pembangunan bangsa dengan tindakan nyata serta prestasi. Berikut penerapan wawasan Nusantara dan Tantangan yang dihadapi dalam perwujudannya di era modern :

\section{Implementasi di Bidang Pertahanan dan Keamanan}

Implementasi wawasan nusantara di bidang pertahanan dilakukan dengan membentuk sikap dan kedisiplinan diri dalam membela Tanah Air, serta melaporkan segala hal yang mengganggu keamanan pada aparat yang berwenang, meningkatkan rasa persatuan serta solidaritas baik dalam satu daerah yang sama atau daerah yang berbeda. Terakhir membangun sarana serta prasarana bagi kegiatan atau aktivitas pengamanan wilayah Indonesia. 


\section{Implementasi di Bidang Politik}

Implementasinya ada dalam Pelaksanaan kehidupan berpolitik Indonesia. Terdapat juga dalam Undang-Undang, misalnya UU Partai Politik, dan UU Pemilu. Implementasi wawasan nusantara di bidang politik juga dimaksudkan untuk menciptakan pemerintahan yang kuat, bersih, dan dapat dipercaya oleh masyarakatnya. Contoh implementasi wawasan nusantara di bidang politik yakni:

Menjalankan komitmen politik pada lembaga pemerintahan serta partai politik dalam rangka meningkatkan persatuan serta kesatuan bangsa. Keikutsertaan Indonesia di dalam politik luar negeri, dan memperkuat korps diplomatik untuk menjaga seluruh wilayah Indonesia. Pelaksanaan Pemilu dengan sistem demokrasi yang menjunjung tinggi keadilan. Mengembangkan sikap pluralisme dan HAM untuk mempersatukan keberagaman di Indonesia

\section{Implementasi di Bidang Ekonomi}

Implementasi wawasan nusantara di bidang ekonomi terdapat pada pemanfaatan kekayaan alam di indonesia sambil menjaga kelestarian lingkungan hidupnya. Kekayaan dan letak geografis Indonesia yang strategis dapat dimanfaatkan dengan maksimal untuk perekonomian negara. Orientasi bidang ekonomi di sektor pemerintahan, industri, serta pertanian. Pembangunan ekonomi yang seimbang serta adil di tiap-tiap daerah Indonesia sehingga tidak terjadi kemiskinan di daerah tertentu. Otonomi daerah sendiri diharapkan dapat atau bisa menciptakan segala macam upaya keadilan ekonomi ini Partisipasi seluruh masyarakat Indonesia dibutuhkan dalam pembangunan ekonomi. Hal ini kemudian akan didukung dengan pemberian fasilitas kredit mikro guna mengembangkan usaha kecil.

4. Implementasi di Bidang Sosial

Implementasi wawasan nusantara di bidang sosial berada pada saling menghargai dan menghormati setiap perbedaan atau keragaman yang ada di Tanah Air. Mulai dari perbedaan, suku, ras, agama hingga budaya. Upaya lainnya juga ada pada pelestarian serta pengembangan budaya Indonesia dan menjadikan budaya sebagai tujuan wisata yang memberikan sumber penghasilan daerah atau nasional. Menjaga keberagaman Indonesia, baik dari segi budaya, bahasa, serta status sosial, dan juga mengembangkan keserasian di dalam kehidupan bermasyarakat. 


\section{E. Kesimpulan}

Secara keseluruhan, wawasan Nusantara merupakan "cara pandang" bangsa Indonesia tentang diri dan lingkungannya. Wawasan tersebut merupakan penjabaran dari falsafah bangsa Indonesia sesuai dengan keadaan geografis suatu bangsa serta sejarah yang pernah dialaminya. Esensinya adalah pelaksanaan dari bangsa Indonesia itu sendiri dalam memanfaatkan kondisi geografis, sejarah, serta kondisi sosial-budayanya dalam mencapai cita-cita dan tujuan nasionalnya. Dengan demikian, wawasan Nusantara juga dapat diartikan sebagai cara pandang bangsa Indonesia tentang diri dan lingkungannya berdasarkan ide nasionalnya yang dilandasi oleh Pancasila dan UUD 1945, yang merupakan aspirasi bangsa yang merdeka, berdaulat, bermartabat, serta menjiwai tata hidup dan tindak kebijaksanaannya dalam mencapai tujuan nasional. Basrie turut menambahkan bahwa wawasan Nusantara adalah cara pandang, cara memahami, cara menghayati, cara bersikap, cara berpikir, cara bertindak, cara bertingkah laku bangsa Indonesia sebagai interaksi proses psikologis, sosio kultural, dengan aspek astagatra (kondisi geografis, kekayaan alam, dan kemampuan penduduk ). 


\section{DAFTAR PUSTAKA}

- Anwar, Choirul Ilham.2021. Perwujudan Kesatuan Bangsa dalam Aspek Politik hingga Hankam

https://tirto.id/perwujudan-kesatuan-bangsa-dalam-aspek-politik-hingga-hankam-gfP8

- Ahmad.2020. Wawasan Nusantara

https://www.gramedia.com/literasi/wawasan-nusantara/

https://id.wikipedia.org/wiki/Wawasan_Nusantara 